
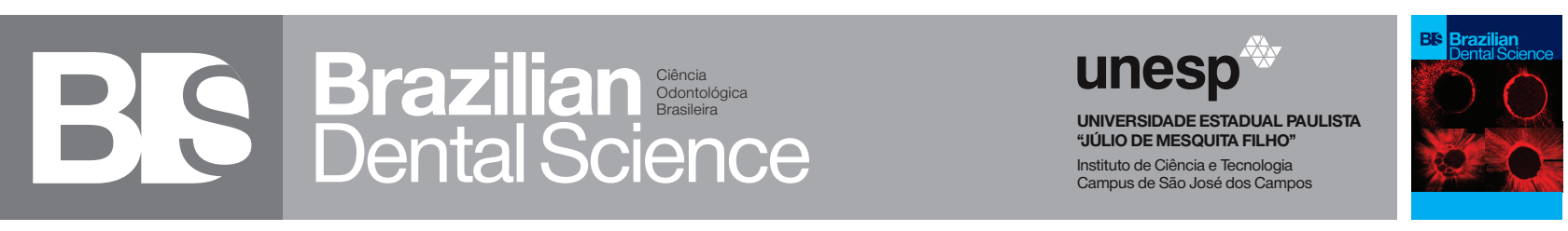

\title{
The Reliability of Fishman and Nolla Methods in Prediction of Chronological Age of Yemeni Children
}

\author{
A confiabilidade dos métodos Fishman e Nolla na predição da idade cronológica de crianças iemenitas \\ Maktoom A. ALQADI ${ }^{1,2}$, Amal H. ABUAFFAN ${ }^{1}$ \\ 1 - Department of Orthodontics, Pedodontics and Preventive Dentistry - Faculty of Dentistry - University of Khartoum - Sudan. \\ 2 - Najran Specialized Dental Center - Ministry of Health - Saudi Arabia
}

\section{ABSTRACT}

Objective: This cross-sectional school based study aimed to assess the reliability of Fishman and Nolla methods in predicting the chronological age for Yemeni children. Material and Methods: Orthopantomographs and left handwrist radiographs were taken for 358 Yemeni children (193 boys and 165 girls) 8 - 16 years. Skeletal age estimated by Fishman method and dental age estimated by Nolla method were compared to chronological age using SPSS version 21, statistical significance was predetermined at $\mathrm{P}$ $<0.05$, using Intraclass Correlation CoefficientICC and Wilcoxon signed rank test. Results: The mean chronological, skeletal and dental ages were $12.00 \pm 2.25$ years, $12.39 \pm 1.65$ years and $11.32 \pm 2.65$ years, respectively. Intraclass correlation coefficient showed strong correlation between chronological age and skeletal and dental ages. Wilcoxon test showed Fishman method significantly underestimated the chronological age by $0.44 \pm 1.26$ years in boys and non-significantly underestimated the chronological age by $0.02 \pm 1.08$ years in girls. Nolla method significantly underestimated the chronological age by $0.59 \pm 1.28$ years in boys and $0.78 \pm 1.21$ years in girls. Conclusions: Chronological age of Yemeni children is highly correlated to skeletal age estimated by Fishman method and dental age estimated by Nolla method. However, the two methods underestimate the chronological age of Yemeni children.

\section{KEYWORDS}

Age determination by teeth; Orthodontics; Age determination by skeleton; Forensic dentistry; Yemen.

\section{RESUMO}

Objetivo: Este estudo transversal de base escolar teve como objetivo avaliar a confiabilidade dos métodos Fishman e Nolla na predição da idade cronológica em crianças iemenitas. Material e Métodos: Foram realizadas ortopantomografias e radiografias do punho esquerdo em 358 crianças iemenitas (193 meninos e 165 meninas) de 8 a 16 anos. A idade esquelética estimada pelo método Fishman e a idade odontológica estimada pelo método Nolla foram comparadas com a idade cronológica pelo, utilizando-se o programa SPSS versão 21 ; a significância estatística foi predeterminada em $\mathrm{P}$ $<0,05$, pelo coeficiente de correlação intraclasseICC e pelo teste de Wilcoxon. Resultados: As idades cronológica, esquelética e odontológica média foram de $12,00 \pm 2,25$ anos, $12,39 \pm 1,65$ anos e 11,32 $\pm 2,65$ anos, respectivamente. O coeficiente de correlação intraclasse mostrou forte correlação entre idade cronológica e idade esquelética e dentária. O teste de Wilcoxon mostrou que o método Fishman subestimou significativamente a idade cronológica em $0,44 \pm 1,26$ anos nos meninos e não subestimou significativamente a idade cronológica em $0,02 \pm$ 1,08 anos nas meninas. O método Nolla subestimou significativamente a idade cronológica em 0,59 $\pm 1,28$ anos nos meninos e $0,78 \pm 1,21$ anos nas meninas. Conclusões: A idade cronológica de crianças iemenitas está altamente correlacionada à idade esquelética estimada pelo método Fishman e à idade dentária estimada pelo método Nolla. No entanto, os dois métodos subestimam a idade cronológica das crianças iemenitas.

\section{PALAVRAS-CHAVE}

Determinação da idade pelos dentes; Ortodontia; Determinação da idade pelo esqueleto; Odontologia forense; Iémen. 


\section{INTRODUCTION}

A

ge estimation has increasingly become of more concerns in several aspects, including orthodontic treatment needs, forensic dentistry and criminal conflicts $[1,2]$. Age of living individual can be estimated by radiological investigation of the dental developmental status [3] or the maturation level of the handwrist [4].

Skeletal age is a dependable method to assess the maturational status [5]. Definite variations in the chronological age was found when different skeletal maturity stages were studied and differences in the timing of skeletal maturity between genders and races were observed. These variations were recommended to be taken into account during orthodontic diagnosis and treatment planning [6].

Abundant age estimating methods were developed based on skeletal maturity or dental development. Fishman method is commonly used with 11 skeletal maturity indicators (SMIs) assessed in the left handwrist radiograph [4].

Flores et al. concluded that the overall maxillofacial growth velocity was related to SMI assessed by handwrist radiographs [7]. Moreover, it was concluded that SMI method was highly valid to discriminate between individual's pre and post pubertal stage and a valid clinical diagnostic index for prediction of peak growth of the maxilla and the mandible [8]. The reliability of SMI method for predicting the chronological age was investigated in several studies, the results were inconsistent [6,9-11].

Nolla method is based on radiographic assessment of dental development of maxillary and mandibular teeth, except third molars [3]. Several studies assessed the validity of Nolla method, most of the obtained results showed underestimation of chronological age [12-15]. While, a few studies showed accuracy $[16,17]$.

The applicability of skeletal and/or dental age estimating method may help to assign the suitable chronological age for interceptive orthodontic intervention without the need of handwrist radiographs and to predict the chronological age of Yemeni children with undocumented birth registration, mainly in rural areas. To the best of our knowledge, this is the first study to assess the reliability of Fishman and Nolla methods for estimating the chronological age of Yemeni children.

\section{MATERIAL AND METHODS}

This cross sectional school based study was a part of broader research work, conducted between February 2015 and February 2019. An ethical approval was obtained from the Faculty of Dentistry, University of Khartoum. Letters were sent by the author via the selected schools to children's parents to be signed for informed consent. The study sample size was calculated using the following equation:

$$
n=\frac{2 *\left(Z_{1-\frac{\alpha}{2}}+Z_{1-\beta}\right)^{2}}{(\bar{d} / S D) 2}
$$

Where:

$\alpha=$ type one error (probability of rejecting true hypothesis) $=0.05$.

$Z_{1-\frac{\alpha}{2}}=$ critical value from standard normal distribution table $=1.96$.

$1-\beta=$ power of the test, sets as $80 \%$.

$Z_{1-\beta}=$ critical value from standard normal distribution table $=0.84$.

$\bar{d}=$ difference in means for matched groups. 


$$
\begin{aligned}
& \text { SD }=\text { standard deviation, calculated as } \\
& \sqrt{\mathrm{S}^{2}+\mathrm{S}^{2}-2 \mathrm{pS} 1 \mathrm{~S} 2} \\
& \mathrm{p}=\text { the correlation coefficient, assumed }
\end{aligned}
$$
as 0.5 .

The denominator $(\bar{d} / \mathrm{SD})=$ effective size.

From previous study conducted on Turkish population (2012) [12], the sample size was calculated. In the Turkish study the mean chronological age and dental age \pm SD for the total sample were $9.94 \pm 1.96$ years and $9.40 \pm 2.21$ years, respectively.

$$
n=\frac{2 *(1.96+0.84)^{2}}{(0 . \overline{54} / 2.1) 2} \quad n=\frac{15.68}{0.066}=238
$$

Therefore, the effective minimum sample size calculated was 238 children. In the present study, the sample was increased to a total of 358 children for more precision and collected by a cluster random sampling technique in three out of the ten directorates of Sana'a capital city. Two public schools from the first directorate, two public schools from the second directorate and three private schools from the third directorate were randomly selected by the authors and the head office of education in Sana'a. Students from each school were conveniently sampled and stratified according to gender and age, with a one year interval (table I).

Table I - Number and percentage of boys and girls within each age group.

\begin{tabular}{|ccccc|}
\hline $\begin{array}{c}\text { Age group } \\
\text { (years) }\end{array}$ & Age range & $\begin{array}{c}\text { Boys } \\
\mathbf{n}(\%)\end{array}$ & $\begin{array}{c}\text { Girls } \\
\mathbf{n}(\%)\end{array}$ & $\begin{array}{c}\text { Total } \\
\mathbf{n}(\%)\end{array}$ \\
\hline 8 & $8-8.99$ & $21(10.9)$ & $23(13.9)$ & $44(12.3)$ \\
\hline 9 & $9-9.99$ & $17(8.8)$ & $18(10.9)$ & $35(9.8)$ \\
\hline 10 & $10-10.99$ & $28(14.5)$ & $21(12.7)$ & $49(13.7)$ \\
\hline 11 & $11-11.99$ & $35(18.1)$ & $24(14.5)$ & $59(16.5)$ \\
\hline 12 & $12-12.99$ & $29(15)$ & $22(13.3)$ & $51(14.2)$ \\
\hline 13 & $13-13.99$ & $21(10.9)$ & $21(12.7)$ & $42(11.7)$ \\
\hline 14 & $14-14.99$ & $16(8.3)$ & $14(8.5)$ & $30(8.4)$ \\
\hline
\end{tabular}

\section{Exclusion criteria}

- Presence of any congenital, nutritional or systemic disorders.

- Presence of periapical lesion or trauma to upper or lower jaw or left handwrist. teeth.

- Congenitally missing or supernumerary

- Children on or previously had orthodontic or oral surgical treatment.

Two digital radiographs (one orthopantomograph - OPG and one left handwrist radiograph - HWR) were taken for each child by the same operator and machine (Pax-Flex3D-Vatech, South Korea) following the manufacturer instructions. All radiographs were collected from the radiology center, checked for anatomical clearness and assessed for age estimation by the author, without prior knowledge of students' age during assessment.

Date of birth was obtained from the birth certificate. Chronological age was calculated in years decimal by subtracting the date of birth from date of radiographing then dividing over 365 .

Skeletal age was calculated according to Fishman method. Each child's left HWR was assessed to assign the SMI, based on scheme suggested by Fishman [4]. Dental age was calculated according to Nolla method [3]. Each tooth of the left upper and lower jaws was given a score (1 through 10) based on its dental developmental stage. All developmental scores of the 14 teeth were summed to give the total score which was converted to dental age in the gender-specific tables suggested by Nolla.

Data was statistically described and analyzed using Statistical Package for the Social Sciences (SPSS), version 21. Descriptive statistics were calculated for the total chronological, dental and skeletal ages 
and comparative analysis was computed to find the difference in means for total children and within age groups for both genders at $\mathrm{P}<$ 0.05. Kolmogorov-Smirnov test showed a nonnormal distribution of the data. Therefore, nonparametric tests were used for correlative and comparative statistics.

The mean chronological age for the total sample was $12.00 \pm 2.25$ years $(12.06 \pm 2.24$ years for boys and $11.94 \pm 2.46$ years for girls). Regression models were formulated to predict the chronological age by skeletal and dental ages.

\section{Error of the method}

Sixty randomly selected cases were rescored after 6 weeks intervals to evaluate the reproducibility of Fishman and Nolla methods, using Dahlberg equation.

$$
D=\sqrt{\frac{\sum \mathrm{d}^{2}}{2 n}}
$$

\section{Dahlberg equation}

Relative error for each method was computed by the equation:

$$
\text { relative error }=\frac{D}{\overline{a g e}} * 100
$$

Where age $=$ mean age of second measurement of the method.

Dahlberg equation showed minimum error values, 0.34 year and 0.33 year representing the relative errors of $3.8 \%$ and $2.8 \%$ for Fishman and Nolla methods, respectively. The two methods presented high reproducibility.

The minimum age was estimated by Nolla method (6.42 years for girls) and the maximum age was estimated by Fishman method (16.4 years for boys). The lowest mean age value was noted in Nolla method (11.46 years for boys and 11.16 years for girls), while the highest was seen in Fishman method (12.53 and 12.25 years for boys and girls, respectively) (table II). According to Fishman method, the first SMI (PP3) appears at age 11.01 years and 9.94 years in boys and girls, respectively. Children who did not reach the first SMI were excluded in all descriptive and comparative statistics whenever skeletal age was used.

Table II - Minimum, maximum, means and standard deviation for the CA, SA and DA for the total children and by gender.

\begin{tabular}{|ccccc|}
\multicolumn{2}{c}{ Variable } & Min. & Max. & Mean (SD) \\
\hline \multirow{4}{*}{ CA (years) } & All $(\mathrm{N}=358)$ & 8.00 & 15.96 & $12.00(2.25)$ \\
& Boys $(\mathrm{n}=193)$ & 8.06 & 15.96 & $12.06(2.24)$ \\
& Girls $(\mathrm{n}=165)$ & 8.00 & 15.92 & $11.94(2.46)$ \\
\hline \multirow{3}{*}{$\mathrm{SA}$ (years) } & All $(\mathrm{N}=292)$ & 9.94 & 16.4 & $12.39(1.65)$ \\
& Boys $(\mathrm{n}=142)$ & 11.01 & 16.4 & $12.53(1.50)$ \\
& Girls $(\mathrm{n}=150)$ & 9.94 & 16.07 & $12.25(1.77)$ \\
\hline \multirow{3}{*}{ DA (years) } & All $(\mathrm{N}=358)$ & 6.42 & 16 & $11.32(2.65)$ \\
& Boys $(\mathrm{n}=193)$ & 6.68 & 16 & $11.46(2.65)$ \\
& Girls $(\mathrm{n}=165)$ & 6.42 & 16 & $11.16(2.64)$ \\
\hline
\end{tabular}

CA: chronological age; SA: skeletal age; DA: dental age; Min: minimum; Max: maximum; SD: standard deviation

Comparisons between chronological age and skeletal and dental ages for all groups and by gender

Intraclass Correlation Coefficient ICC showed a strong correlation between chronological age and skeletal and dental ages, for the total sample and by gender ( $P$ $<0.001$ ). Wilcoxon signed rank test showed statistically significant differences between chronological age and skeletal age for total boys $(P=0.001)$ and statistically significant difference between chronological age and dental age for total boys and total girls ( $\mathrm{P}<$ 0.001) (table III).

The chronological age for the total children was significantly underestimated by Fishman and Nolla methods $(\mathrm{P}=0.02$ and $\mathrm{P}<0.001$, respectively). Boys were underestimated by both methods, the minimum underestimation was noted with 
Fishman method $(0.44 \pm 1.26, \mathrm{P}=0.001)$. For girls, no significant difference was seen between chronological age and skeletal age $(\mathrm{P}=0.898)$, while Nolla method showed significant age underestimation of $0.77 \pm$ 1.21 ( $\mathrm{P}<0.001)$ (table III).

Fishman method significantly overestimated the younger age groups; 8,9 and 10 years and underestimated the older age groups; 12, 14 and 15 years. While Nolla method underestimated all age groups, except the age groups 13 and 14 years.

Table III - Comparisons between CA and SA and DA for the total children and by gender.

\begin{tabular}{|c|c|c|c|c|c|}
\hline \multicolumn{2}{|c|}{ Comparison } & $\begin{array}{c}\text { Mean } \\
\text { Difference }\end{array}$ & $P$-value & $\begin{array}{c}\text { ICC } \\
(95 \% \text { CI) }\end{array}$ & $P$-value \\
\hline \multirow{2}{*}{$\begin{array}{c}\mathrm{CA} \\
\text { (total) }\end{array}$} & $S A(n=292)$ & $0.23(1.19)$ & $0.02^{*}$ & $0.88(0.85-0.91)$ & $<0.001^{\star}$ \\
\hline & $D A(n=358)$ & $0.68(1.25)$ & $<0.001^{*}$ & $0.93(0.91-0.94)$ & $<0.001^{*}$ \\
\hline \multirow{2}{*}{$\begin{array}{c}\mathrm{CA} \\
\text { (boys) }\end{array}$} & $S A(n=142)$ & $0.44(1.26)$ & $0.001^{\star}$ & $0.83(0.77-0.88)$ & $<0.001^{*}$ \\
\hline & $\mathrm{DA}(\mathrm{n}=193)$ & $0.59(1.28)$ & $<0.001^{\star}$ & $0.93(0.90-0.95)$ & $<0.001^{\star}$ \\
\hline $\begin{array}{c}\mathrm{CA} \\
\text { (girls) }\end{array}$ & $\begin{array}{l}S A(n=150) \\
D A(n=165)\end{array}$ & $\begin{array}{l}0.02(1.08) \\
0.78(1.21)\end{array}$ & $\begin{array}{c}0.898 \\
<0.001^{*}\end{array}$ & $\begin{array}{l}0.92(0.89-0.94) \\
0.94(0.91-0.95)\end{array}$ & $\begin{array}{l}<0.001^{\star} \\
<0.001^{\star}\end{array}$ \\
\hline
\end{tabular}

CA: chronological age; SA: skeletal age; DA: dental age; SD: standard deviation; ICC: intraclass correlation coefficient; $\mathrm{Cl}$ : confidence interval; *: significance at $\mathrm{P}<0.05$.

In table IV statistically significant differences between chronological age and skeletal age were found in all age groups except for the age groups 11 years for boys and 11, 12, 13 and 14 years for girls. Boys in 8 and 9 age groups were not included in the comparison because of very few or lack of number in the two age groups.

Statistically significant differences were found between chronological age and dental age in all age groups, except 13,14 and 15 years for boys and 9,13,14 and 15 years for girls.
Table IV - Comparison between CA and SA and DA for all age groups and by gender.

\begin{tabular}{|c|c|c|c|c|c|c|}
\hline \multirow{2}{*}{$\begin{array}{c}\text { Age } \\
\text { group }\end{array}$} & \multirow{2}{*}{$\begin{array}{l}\text { Gen- } \\
\text { der }\end{array}$} & \multirow{2}{*}{ Mean CA } & \multirow{2}{*}{ Mean SA } & \multirow{2}{*}{ Mean DA } & \multicolumn{2}{|c|}{$\begin{array}{c}\text { Mean SA } \\
\boldsymbol{P} \text {-value }\end{array}$} \\
\hline & & & & & $\begin{array}{c}\text { CA vs. } \\
\text { SA }\end{array}$ & $\begin{array}{c}\text { CA vs. } \\
\text { DA }\end{array}$ \\
\hline \multirow{2}{*}{8} & $\begin{array}{l}\text { Boys } \\
(n=21)\end{array}$ & $8.5(0.26)$ & $11.01(0)^{\mathrm{a}}$ & $8.09(0.62)$ & NC & $0.006^{\star}$ \\
\hline & $\begin{array}{c}\text { Girls } \\
(n=23)\end{array}$ & $8.63(0.29)$ & $10.22(0.34)^{b}$ & $7.77(0.82)$ & $0.008^{\star}$ & $<0.001^{\star}$ \\
\hline \multirow{2}{*}{9} & $\begin{array}{l}\text { Boys } \\
(n=17)\end{array}$ & $9.43(0.24)$ & $N A^{c}$ & $8.54(1.07)$ & NA & $0.005^{\star}$ \\
\hline & $\begin{array}{c}\text { Girls } \\
(n=18)\end{array}$ & $9.61(0.33)$ & $10.46(0.34)^{d}$ & $9.19(0.91)$ & $<0.001^{*}$ & 0.145 \\
\hline \multirow{2}{*}{10} & $\begin{array}{c}\text { Boys } \\
(n=28)\end{array}$ & $10.56(0.27)$ & $11.17(0.29)^{\mathrm{e}}$ & $9.8(1.11)$ & $<0.001^{\star}$ & $0.001^{\star}$ \\
\hline & $\begin{array}{c}\text { Girls } \\
(n=21)\end{array}$ & $10.54(0.34)$ & $10.96(0.6)$ & $9.71(1.06)$ & $0.002^{\star}$ & $0.003^{\star}$ \\
\hline \multirow{2}{*}{11} & $\begin{array}{l}\text { Boys } \\
(n=35)\end{array}$ & $11.48(0.27)$ & $11.58(0.42)^{f}$ & $10.68(1.21)$ & 0.357 & $0.001^{\star}$ \\
\hline & $\begin{array}{c}\text { Girls } \\
(n=24)\end{array}$ & $11.35(0.26)$ & $11.1(0.86)$ & $9.9(1.14)$ & 0.17 & $\ll 0.001^{\star}$ \\
\hline \multirow{2}{*}{12} & $\begin{array}{c}\text { Boys } \\
(n=29)\end{array}$ & $12.59(0.28)$ & $12.12(0.83)$ & $11.66(1.39)$ & $0.005^{\star}$ & $0.001^{\star}$ \\
\hline & $\begin{array}{c}\text { Girls } \\
(n=22)\end{array}$ & $12.56(0.32)$ & $12.33(0.84)$ & $11.75(1.3)$ & 0.095 & $0.004^{*}$ \\
\hline \multirow{2}{*}{13} & $\begin{array}{l}\text { Boys } \\
(n=21)\end{array}$ & $13.58(0.26)$ & $12.8(1.22)$ & $13.82(1.58)$ & $0.017^{\star}$ & 0.414 \\
\hline & $\begin{array}{l}\text { Girls } \\
(n=21)\end{array}$ & $13.57(0.31)$ & $13.53(1.21)$ & 13.24 (1.22) & 0.689 & 0.23 \\
\hline \multirow{2}{*}{14} & $\begin{array}{l}\text { Boys } \\
(n=16)\end{array}$ & $14.62(0.29)$ & $13.32(1.49)$ & $14.27(1.43)$ & $0.005^{\star}$ & 0.469 \\
\hline & $\begin{array}{c}\text { Girls } \\
(n=14)\end{array}$ & $14.52(0.29)$ & $13.84(1.2)$ & 13.99 (1.64) & 0.096 & 0.331 \\
\hline \multirow{2}{*}{15} & $\begin{array}{c}\text { Boys } \\
(n=26)\end{array}$ & $15.62(0.29)$ & $14.46(1.44)$ & $15.09(1.24)$ & $<0.001^{\star}$ & 0.104 \\
\hline & $\begin{array}{c}\text { Girls } \\
(n=22)\end{array}$ & $15.46(0.28)$ & $14.63(1.06)$ & $14.7(1.48)$ & $0.001^{\star}$ & 0.058 \\
\hline
\end{tabular}

CA: chronological age; SA: skeletal age; DA: dental age; $a$ : $n=2$; b: $n=9 ; \mathrm{c}: \mathrm{n=0}$ d: $n=17$; e: $n=17 ;$ f: $n=31$; NA: not applicable; NC: not computed; *: significance at $P<0.05$.

Regression models for predicting the CA using Fishman and Nolla methods:

Very narrow confidence intervals were found for intercept and slope, for both methods and genders $(\mathrm{P}<0.001)$ (table V).

For Fishman method, the equation $(\mathrm{y}=\mathrm{a}+\mathrm{b} * \mathrm{x})$ was used to predict the chronological age. Where: $\mathrm{y}=$ chronological age, $\mathrm{x}=$ skeletal age estimated by Fishman method, $\mathrm{a}=$ constant, $\mathrm{b}=$ slope. The equations assumed were: $(y=9.21+0.31 * x)$ for boys and $(y=7.14+0.43 * x)$ for girls. The variability of 
the chronological age due to skeletal age was $61 \%$ and $55 \%$ for boys and girls, respectively. The assumed equations are highly significant for prediction of chronological age by Fishman method $(\mathrm{P}<0.001)$ (table V).

For Nolla method, the equation $(\mathrm{y}=\mathrm{a}$ $+\mathrm{b} * \mathrm{x}$ ) was used to predict the chronological age. Where: $y=$ chronological age, $x=$ dental age estimated by Nolla method, $\mathrm{a}=$ constant, $\mathrm{b}=$ slope. The equations assumed were: $(y=3.58+0.74 * x)$ for boys and $(y=3.41+0.76 * x)$ for girl. The variability of the chronological age due to dental age was $77 \%$ and $79 \%$ for boys and girls, respectively. The assumed equations are highly significant for prediction of chronological age by Nolla method $(\mathrm{P}<0.001)$ (table V).

Table V - Regression analysis showing adjusted $\mathrm{R}$ square using Fishman and Nolla methods.

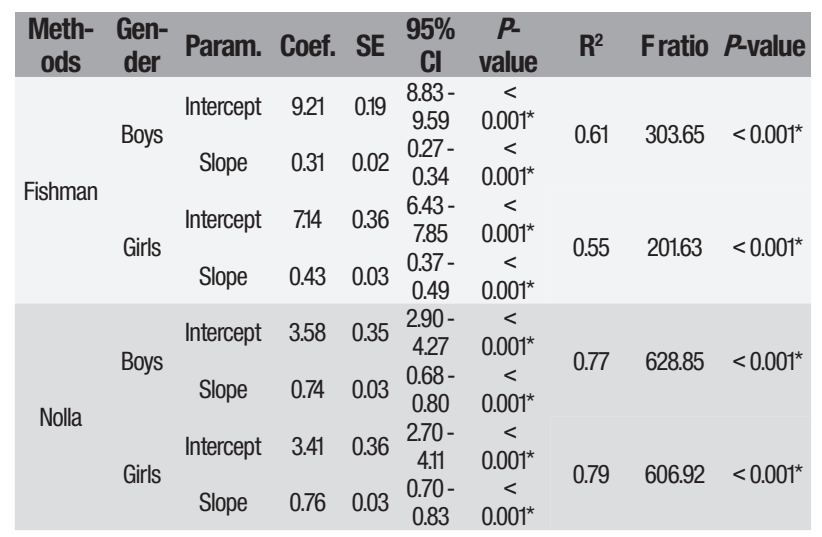

Para: parameter; Coef: coefficient; SE: standard error; Cl: confidence intervals; *: significance at $\mathrm{P}<0.05$.

\section{DISCUSSION}

In the current study, Fishman and Nolla methods were used to predict the chronological age. The two methods showed high reproducibility, with very low relative error. The first stage of skeletal maturation according to Fishman method (PP3) starts at age 11.01 and 9.94 years for boys and girls, respectively. The lower limit of the children age in this study was 8 years, children who did not reach PP3 stage were excluded from statistical comparisons since they could not be scored by Fishman method.

High correlation coefficient value was observed between chronological age and skeletal age, being higher for girls than boys. This finding was in agreement with other studies $[9,11]$.

For the total boys in the study, the mean difference between skeletal age and chronological age was statistically significant and not significant for the total girls. For boys and girls individually, Fishman method was more accurate among girls than boys. For girls, no significant difference was seen in the age groups 11, 12, 13 and 14 years old. The younger age groups ( 8,9 and 10 years) were significantly overestimated and the older age group (15 years) was significantly underestimated. For boys, no significant difference was seen in the age group 11 years only. The age group 10 years was significantly overestimated and the older age groups $12,13,14$ and 15 years were significantly underestimated. The boys in the age groups 8 and 9 years were not compared due to no or very small number of boys. Overestimation of the younger age groups may be attributed to inability of the method to estimate the skeletal age of children under 10 and 11 years for girls and boys, respectively.

Mohammed et al. [11] found statistically insignificant difference between chronological and skeletal ages among Indian girls in age groups 12, 13 and 14, in agreement with the current study results. While Saade et al. [9] found statistically significant overestimation for all age groups between 8 and 16 years Lebanese children, the incompatibility with this study findings may be attributed to sample size, group age intervals or other environmental and genetic factors.

The linear regression analysis showed 
moderate adjusted $\mathrm{R}$ square values which indicate that Fishman method explains 61\% and 55\% for boys and girls, respectively of the variability of chronological age due to skeletal age.

In this study, strong correlation was found between chronological and dental ages. This was in agreement with studies carried out on different population $[16,18]$. On the other hand, Bala et al. reported inconsistent relationship between chronological and dental age estimated by Nolla method for Northern Indian children [19].

However, in the present study, statistically significant differences were found between chronological age and dental age estimated by Nolla method for the total boys and total girls individually. Nolla method tends to estimate accurately the age of older groups more than the younger groups for both genders. The chronological age was significantly underestimated in the younger age groups $(8,9,10,11$ and 12 years for boys and 8,10,11 and 12 years for girls). No statistically significant differences were observed in the older age groups (13,14 and 15 years for boys and 9,13,14 and 15 years for girls).

Nur et al. found statistically significant difference in the younger age groups and not in the older age groups for both northeastern Turkish boys and girls, in agreement with the current study findings [13]. Melo and Ata-Ali found underestimation in all age groups of Spanish children aged 7-21 years [17]. Moreover, Sinha et al. recorded underestimation value upto $3.14 \pm 0.06$ years for Indian children aged 10-15 years [14] and Kurita et al. observed underestimation among Brazilian children aged 7-15 years in both genders [20].

The linear regression analysis showed high adjusted $\mathrm{R}$ square values which indicate that Nolla method explains $77 \%$ and $79 \%$ for boys and girls, respectively of the variability of chronological age due to dental age.

Different drawbacks related to Nolla method include involvement of arbitrary full root length measurements, dental age is given in years without months so the age in years and months has to be calculated mathematically. Moreover, there are 40 dental assessment stages and interstages scoring. The increased number of assessment stages makes the method more complicated and less precise, but more accurate in the older ages, since the interval between the scores of dental ages is narrower than that in the younger groups. For example, dental scores for the two ages 9 and 10 years are 118 and 127.7, respectively, while the dental scores for the ages 14 and 15 years are 139.1 and 139.6, respectively.

Additionally, $\mathrm{R}$ square values for the line of best fit were higher with Nolla method compared to Fishman method for both genders in the present study, indicating that the regression models with Nolla method are more accurate than that with Fishman method for predicting the chronological age of Yemeni children.

Variations between chronological age and skeletal and dental ages support the idea of revising and updating the available estimating methods. Variations among different populations may be partially attributed to either statistical tests applied, sample size, age groups and intervals, study population or to other factors.

Liversidge correlated the variations to the level of similarity in maturity of individual tooth formation stages between populations [21]. The genetics have the main and prominent role in controlling the timing and rate of development of teeth [22]. It may also be attributed to a positive secular trend in growth and development between the generations 
[23], changes in socio-economic condition [24], fluctuations in pubertal growth period [25] or to large malnutritional range [26].

It was suggested that one year difference between chronological age and dental age is considered as normally accepted for legal authorities and forensic anthropology [27]. Therefore, Nolla method is suitable for predicting the chronological age, whereas Fishman method is accurate to estimate the skeletal maturity stages, since it represents a clear and easily identified SMI stages [11].

\section{Study limitation}

The regression models suggested in this study need to be validated.

\section{CONCLUSIONS}

Within the limits of this study results, it is concluded that there is a strong correlation between chronological age and skeletal age estimated by Fishman method and dental age estimated by Nolla method. Yemeni children are delayed in skeletal maturity and dental development when compared to Fishman and Nolla age standards. Chronological age of Yemeni children is unsuitable dependent timing for orthodontic intervention. Skeletal age remains essential for clinical orthodontic practices, while dental age estimated by Nolla method is a helpful mean for prediction of unknown chronological age for Yemeni boys and girls aged between 13 and 16 years for civil and forensic purposes.

\section{Financial or other competing interests:} None.

Financial grants: The study work was self-funded.

Acknowledgments: Our thanks to the principals, parents and children of all schools participated in the study sample. Worm greetings to Dr. Mohammed Nasser Alhaj for his assistance.

\section{REFERENCES}

1. Krailassiri S, Anuwongnukroh N, Dechkunakorn S. Relationships between dental calcification stages and skeletal maturity indicators in Thai individuals. Angle Orthod. 2002;72(2):155-66. doi:10.1043/00033219(2002)072«0155:RBDCSA»2.0.C0;2

2. Willems G. A review of the most commonly used dental age estimation techniques. J Forensic Odontostomatol. 2001;19(1):9-17.

3. Nolla CM. The development of the permanent teeth. J Dent Child. 1960;27:254-66.

4. Fishman LS. Radiographic evaluation of skeletal maturation. A clinically oriented method based on hand-wrist films. Angle Orthod. 1982;52(2):88112. doi:10.1043/0003-3219(1982)052«0088:REOSM»2.0.C0;2

5.

6. 5. Kiran S, Sharma VP, Tandon P, Tikku T, Verma S, Srivastava K. To establish the validity of dental age assessment using Nolla's method on comparing with skeletal age assessed by hand-wrist radiographs. J Orthod Res. 2013;(1):11-5.

7.

8. 6. Soegiharto BM, Cunningham SJ, Moles DR. Skeletal maturation in Indonesian and white children assessed with hand-wrist and cervical vertebrae methods. Am J Orthod Dentofacial Orthop. 2008;134(2):217-26. doi:10.1016/j.ajodo.2006.07.037

9. Flores-Mir C, Nebbe B, Major PW. Use of skeletal maturation based on hand-wrist radiographic analysis as a predictor of facial growth: a systematic review. Angle Orthod. 2004;74(1):118-24. doi:10.1043/00033219(2004)074«0118:UOSMB0»2.0.C0;2

10. Soegiharto BM, Moles DR, Cunningham SJ. Discriminatory ability of the skeletal maturation index and the cervical vertebrae maturation index in detecting peak pubertal growth in Indonesian and white subjects with receiver operating characteristics analysis. Am J Orthod Dentofacial Orthop. 2008;134(2):227-37. doi:10.1016/j.ajodo.2006.09.062

11. Saadé A, Baron P, Noujeim Z, Azar D. Dental and skeletal age estimations in lebanese children: a retrospective cross-sectional Study. J Int Soc Prev Community Dent. 2017;7(3):90-7. doi:10.4103/jispcd.JISPCD_139_17.

12. Camacho-Basallo P, Yáñez-Vico RM, Solano-Reina E, Iglesias-Linares A. Five radiographic methods for assessing skeletal maturity in a Spanish population: is there a correlation?. Acta Odontol Scand. 2017;75(2):106-12. doi:10.1080/00016357.2016.1265145.

13. Mohammed RB, Kalyan VS, Tircouveluri S, Vegesna GC, Chirla A, Varma DM. The reliability of Fishman method of skeletal maturation for age estimation in children of South Indian population. J Nat Sci Biol Med. 2014:5(2):297-302. doi:10.4103/0976-9668.136170.

14. Kırzıoğlu Z, Ceyhan D. Accuracy of different dental age estimation methods on Turkish children. Forensic Sci Int. 2012;216(1-3):61-7. doi:10.1016/j.forsciint.2011.08.018.

15. Nur B, Kusgoz A, Bayram M, Celikoglu M, Nur M, Kayipmaz S, et al. Validity of demirijan and nolla methods for dental age estimation for Northeastern Turkish children aged 5-16 years old. Med Oral Patol Oral Cir Bucal. 2012;17(5):e871-e7.Published 2012 Sep 1. doi:10.4317/medoral.18034.

16. Sinha S, Umapathy D, Shashikanth MC, Misra N, Mehra A, Singh AK. Dental age estimation by Demirjian's and Nolla's method: A comparative study among children attending a dental college in Lucknow (UP). J Indian Acad Oral Med Radiol. 2014;26(3):279-86. doi: 10.4103/0972-1363.145005. 
17. Martínez Gutiérrez VM, Ortega-Pertuz Al. Comparison of Nolla Demirjian and Moorrees methods for dental age calculation for forensic purposes. Rev Odont Mex. 2017;21(3):155-64. https://doi.org/101016/j. rodmex.2017.09.011.

18. Hegde S, Patodia A, Dixit U. A comparison of the validity of the Demirjian, Willems, Nolla and Häävikko methods in determination of chronological age of 5-15 year-old Indian children. J Forensic Leg Med. 2017;50:49-57. doi:10.1016/j.jflm.2017.07.007.

19. Melo M, Ata-Ali J. Accuracy of the estimation of dental age in comparison with chronological age in a Spanish sample of 2641 living subjects using the Demirjian and Nolla methods. Forensic Sci Int. 2017;270:276.e1-276.e7. doi:10.1016/j.forsciint.2016.10.001.

20. Altunsoy M, Nur BG, Akkemik 0, Evren 0, Evcil MS. Dental age assessment: validity of the Nolla method in a group of western Turkish children. Marmara Dent J. 2013;1(2):49-52.

21. Bala M, Pathak A, Jain RL. Assessment of skeletal age using MP3 and hand-wrist radiographs and its correlation with dental and chronological ages in children. J Indian Soc Pedod Prev Dent. 2010;28(2):95-9. doi:10.4103/0970-4388.66746.

22. Kurita LM, Menezes AV, Casanova MS, Haiter-Neto F. Dental maturity as an indicator of chronological age: radiographic assessment of dental age in a Brazilian population. J Appl Oral Sci. 2007;15(2):99-104. doi:10.1590/ s1678-77572007000200005.
23. Liversidge HM. Interpreting group differences using Demirian's dental maturity method. Forensic Sci Int. 2010;201(1-3):95-101. doi:10.1016/j. forsciint.2010.02.032.

24. Murata M, Hibi I. Nutrition and the secular trend of growth. Horm Res. 1992;38 Suppl 1:89-96. doi:10.1159/000182578.

25. Liversidge HM, Speechly T, Hector MP. Dental maturation in British children: are Demirjian's standards applicable? Int J Paediatr Dent. 1999;9(4):263-9. doi:10.1111/j.1365-263x.1999.00144.X.

26. Ozer BK. Growth reference centiles and secular changes in Turkish children and adolescents. Econ Hum Biol. 2007;5(2):280-301. doi:101016/j. ehb.2007.03.007.

27. Akkaya N, Yilanci HÖ, Göksülük D. Applicability of Demirjian's four methods and Willems method for age estimation in a sample of Turkish children. Leg Med (Tokyo). 2015;17(5):355-9. doi:10.1016/j. legalmed.2015.04.003

28. Garn SM, Lewis AB, Kerewsky RS. Genetic, nutritional, and maturational correlates of dental development. J Dent Res. 1965;44(1):228-42. doi:10.117 7/00220345650440011901.

29. Chaillet N, Nyström M, Kataja M, Demirjian A. Dental maturity curves in Finnish children: Demirjian's method revisited and polynomial functions for age estimation. J Forensic Sci. 2004;49(6):1324-1331.
Dr. Maktoom Alqadi

(Corresponding address)

E-mail: m73827842@gmail.com
Date submitted: 2019 Dec 12

Accept submission: 2020 Mar 24 